\title{
Studies in the Phylogeny of the Filicales.
}

\author{
VIII. On Loxsoma and Loxsomopsis.
}

\author{
BY \\ LIBRARY \\ NEW YORK \\ F. O. BOWER. \\ BOTANICAL
}

With six Figures in the Text.

TOXSOMA Cunninghamii, R. Br., is a Fern which has always commanded attention from the time of its first discovery by Allen Cunningham. ${ }^{1}$ Its endemic occurrence in New Zealand, together with its peculiarities of structure, marked it out for over half a century as the sole living representative of a distinct family of the Loxsomaceae, and indicated for it a problematic position in the system. It appeared to be a solitary surviving, synthetic type. A relatively primitive position was indicated for it in some degree by its habit, and also by its anatomy with solenostelic rhizome and undivided leaf-trace, now fully known by the work of GwynneVaughan ${ }^{2}$ and of McLean Thompson ; ${ }^{3}$ by its investiture of hairs, without any flattened scales: but more particularly by the position and characters of its sori and sporangia.

The sorus is strictly marginal in position, with a cup-like indusium surrounding the cylindrical receptacle, which bears the sporangia in basipetal sequence. These characters suggested a relationship to the Hymenophyllaceae; but on the other hand the facts would also countenance comparison with Thyrsopteris. The sporangia are, however, distinctive from either, for they alone among those of gradate Ferns dehisce along a median plane, while only a fraction of the oblique annulus is indurated ; the rest of it consists of thin-walled cells, which nevertheless are still to be recognized as a continuous oblique ring. This endemic New Zealand species remained thus for nearly sixty years an isolated type.

In I904 a closely related Fern, discovered by Werckle and Brune in Costa Rica, was described by Christ under the name of Loxsomopsis costaricensis, Christ. ${ }^{4}$ This discovery was quickly followed by others, viz. $L$. Lehmannii, Hier, ${ }^{5}$ from Ecuador, and L. notabilis, Slosson, collected in

1 Hooker : Comp. to Bot. Mag., 366, I8 36 .

2 Ann. of Bot., vol. xv, p. $7 \mathrm{I}$.

${ }^{3}$ Trans. Roy. Soc., Edin., vol. lii, p. $7 \mathrm{I}_{5}$.

${ }^{4}$ Bull. l'Herbier Boissier, ii, 4, p. 399, tom. I. $\quad{ }^{5}$ Engler's Jahrb., vol. xxxiv, p. 435, 1904.

[Annals of Botany, Vol. XXXVII. No. CXLVII. July, 1923.] 
I 902 near Apolo in Bolivia at a level of 6,000 feet by Mr. R. S. Williams, and described by Miss Slosson. ${ }^{1}$ Thus the new genus Loxsomopsis appears to be widely spread in Central America, a habitat far removed from its nearest congener Loxsoma. Small portions of a dry specimen of the last-named species, together with photographs, having been most kindly sent to me by the officials of the Smithsonian Institution, Washington, B.C., I am able to contribute some notes on this interesting Fern from personal observation. These, assisted by the description and drawings already published by Miss Slosson, may form a basis for further discussion of the relations of the genera Loxsoma and Loxsomopsis.

L. notabilis is a stately Fern of Bracken-like habit, its rather slim fronds rising to a height of as much as eight feet : this is a much greater height than that of Loxsoma, though the diameter of the rhizome is less. The general characters of the leaf resemble those of Loxsoma, but with minor differences of outline, surface, and vestiture. The sori are constructed on the same gradate plan. They are marginal on the ends of anadromic veinbranches, and are curved strongly downwards. When ripe the sporangia project from the cup-like indusium, owing, as in Loxsoma, to intercalary lengthening of the base of the receptacle (Fig. I).

The hairs are characteristic. The rhizome is closely invested by stiff bristles. The upper part of each is formed of a simple chain of cells. Passing downwards, this widens conically towards its base, with numerous cell-divisions, both longitudinal and transverse. A turgid insertion is thus produced. It is not a flattened scale, but the base of each hair stands out from the surface as a pear-shaped boss. The size may vary even in closely grouped hairs (Fig. 2). This is essentially what is found also in Loxsoma. The lower surface of the lamina, on the other hand, bears numerous soft curved hairs without any basal swelling (Fig. 3).

The rhizome is cylindrical and rather thin, being about $3.5 \mathrm{~mm}$. in diameter, which is odd, seeing that the frond is so tall. The cortex is much narrower than in Loxsoma, and surrounds a solenostele in all essentials resembling that typical example of solenostely. The departure of the leaf-trace was not observed, but sections of the rachis above the second pair of pinnae show a structure like that observed by Gwynne-Vaughan in Loxsoma. ${ }^{2}$ It is an undivided meristele, and presumably the leaf-trace itself is also undivided. Thus the similarity of the vegetative region of Loxsomopsis in form and structure to that of Loxsoma amply bears out the close relationship of the two genera recognized by Christ, and indicates for both a relatively primitive position.

This is further established by comparison of the sori as a whole, as may be seen from Fig. I. The elongating receptacle bears the sporangia in

1 Bull. Torrey Club, vol. xxxix, p. 285 , Pl. XXIII, I904.

${ }^{2}$ Ann. of Bot., vol. xv, Pl. III, Figs. 8 and $7 d$. 
gradate sequence interspersed with curved hairs of the same nature as those seen in Loxsoma. ${ }^{1}$ The general likeness of the sori makes only the more striking the difference of their sporangia both in form and as regards dehiscence. Their form in Loxsomopsis is pear-shaped, though less markedly so than in Loxsoma. The stalk is short, and consists of about six rows of cells (Fig. 4). The basal face is here less convex and smaller in proportion, but the distal face is larger and flatter than in Loxsoma. Accord-

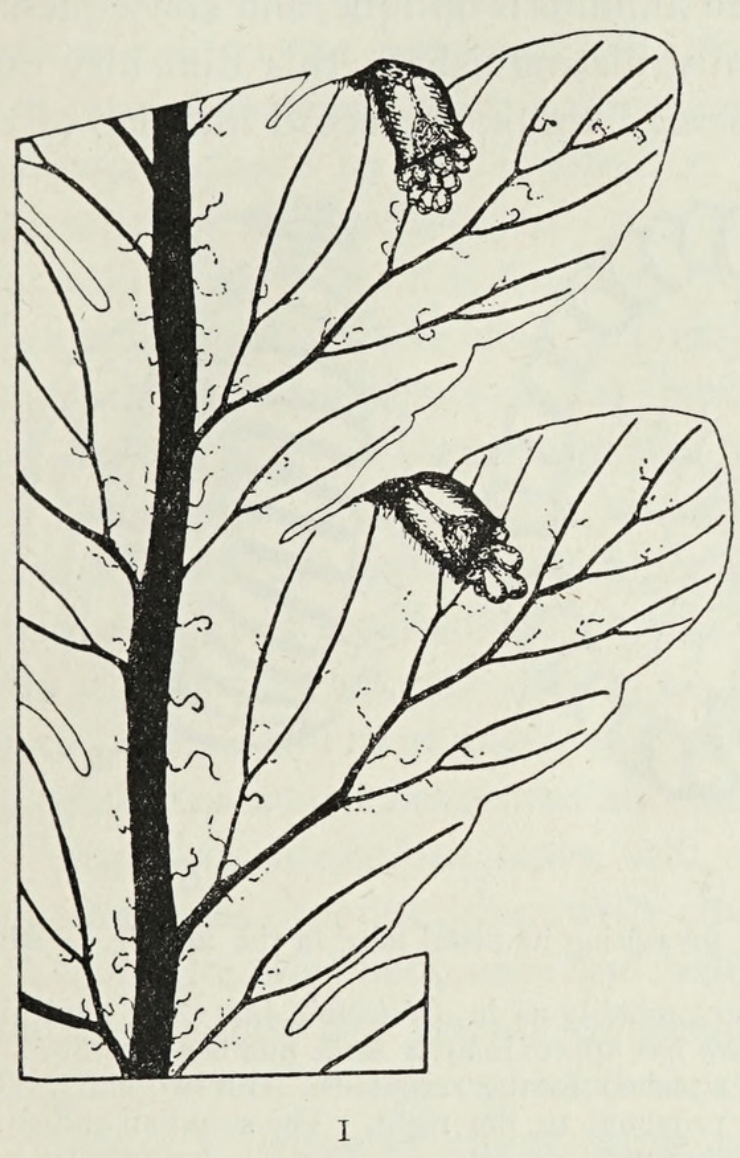

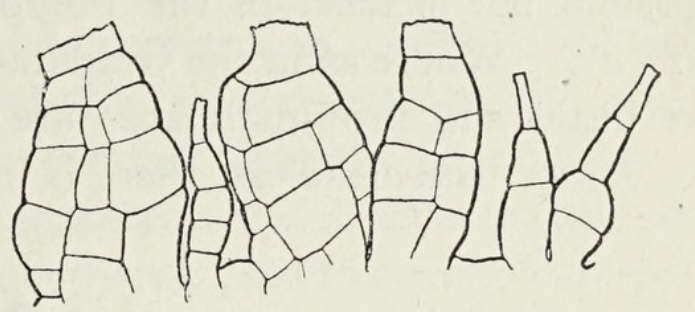

2
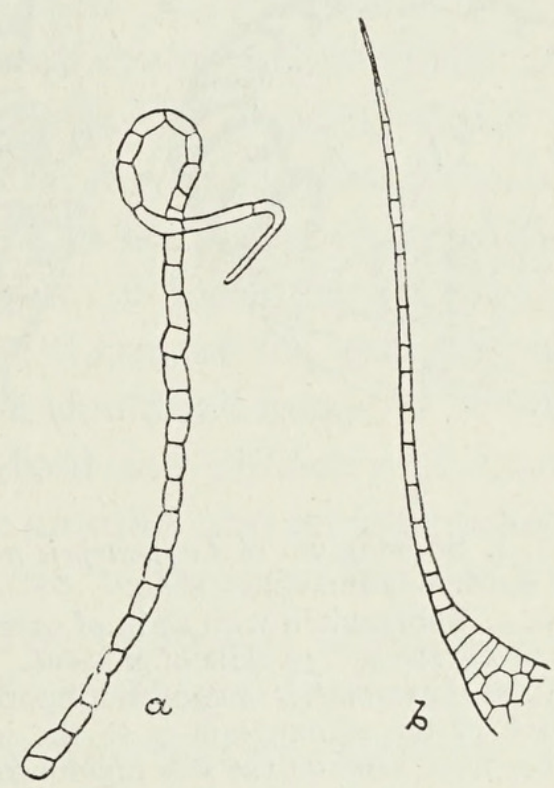

3

FIG. I. Part of pinna of Loxsomopsis notabilis seen from below, showing two pinnules each with a sorus arising from an anadromous vein: in position and structure they closely resemble those of Loxsoma. $x$ Io.

FIG. 2. Bases of hairs of Loxsomopsis notabilis of different structure, in juxtaposition on surface of rhizome. The ends of the hairs were broken off short in preparation. $\times 100$.

FIG. 3. $a=$ soft hair from leaf. $b=$ stiff bristle with enlarged base from the rhizome. After M. Silosson.

ingly the annulus, which here also may be recognized as a complete ring, appears nearly vertical. Its cells are indurated round fully three-quarters of the whole ring. The number of its cells is about 40, or less, and about twelve of these in an obliquely lateral position are relatively narrow and thin walled. The actual rupture takes place about the middle of a group of eight cells which constitute the stomium.

The position of the stomium and of the slit of dehiscence is lateral.

i See Bower: The Ferns, Cambridge Press, vol. i, 1923, Fig. 206.

A a 2 
lying obliquely below the equator of the sporangium ; but, as shown by comparison of Figs. 4, 5, 6, it may be either right or left of the stalk. I do not remember any previously recorded example of this. The fact has an interest in the general theory of the annulus, and of its relation to the whole sporangium. Clearly where the annulus is vertical, as in the Polypodiaceae, the distal face of the sporangium can only be distinguished from the proximal by a careful analysis. In the sporangia of Dryopteris this is possible, but in most of the Polypodiaceae it would be at least extremely difficult. Where as in the Gradatae the annulus is oblique, and consequently the distal and proximal faces are really distinguished, this difficulty does not arise. Nevertheless, there is in them, I think, no record hitherto of the

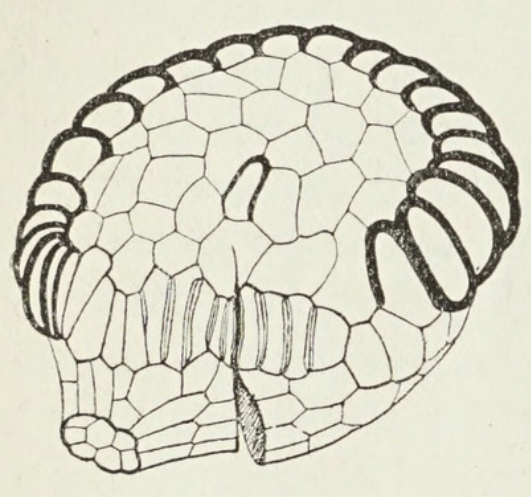

4

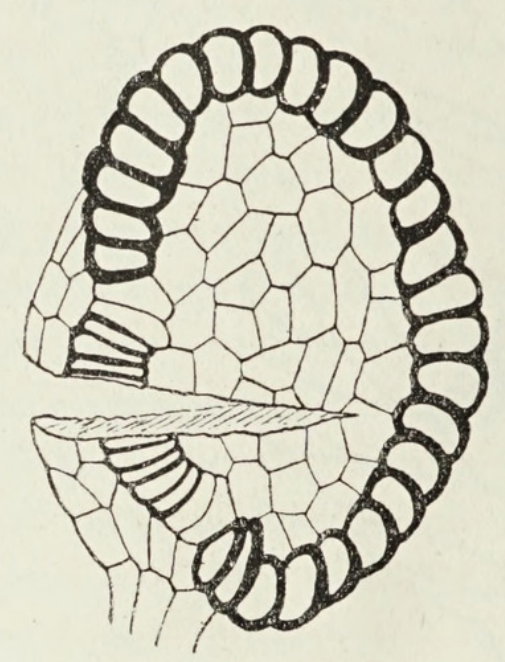

5

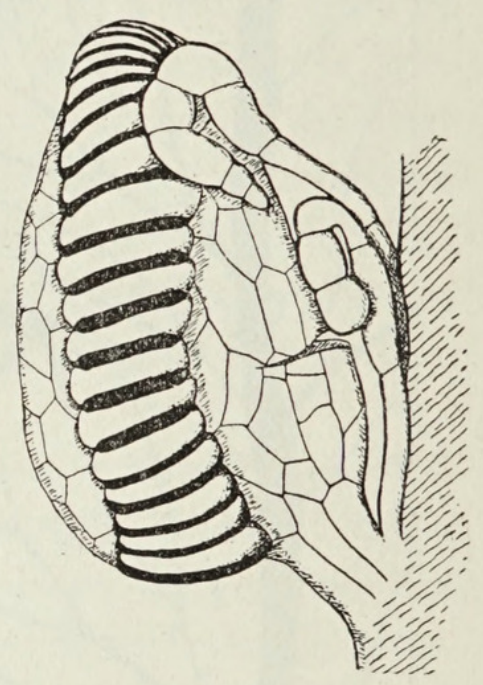

6

FIG. 4. Sporangium of Loxsomopsis notabilis, presenting its distal face, in the middle of which one cell appears indurated. $\times 80$.

FIG. 5. Sporangium with stalk of several rows probabiy as in Dicksonia, but short conical in form as in Loxsoma. 39 cells of annulus. Loxsoma has approximately same number. $\times 80$.

FIG. 6. Loxsomopsis notabilis. Sporangium attached to the receptacle, with two hairs. The distal face of the sporangium is to the left, the proximal to the right. The stomium and slit of dehiscence have been on the side remote from the observer. $\times 80$.

fact that the dehiscence may be either right or left in the same Fern. Comparison of Figs. 4, 5, 6, puts the fact beyond doubt. In Figs. 5 and 6 the dehiscence is on the left-hand side of the distal face as it would be seen in surface view; in Fig. 4 it is on the right. This variability of position will be found interesting in the detailed comparison of the sporangia of Loxsoma and Loxsomopsis. It is difficult to make correct spore-enumerations from dry material. But such observations as have been possible in L. costaricensis and in $L$. notabilis point in both species to a number of not less than sixty-four in each normal sporangium.

Comparing the sporangia of Loxsomopsis with the well-known structure of those of Loxsoma, the general type is the same, with a relatively thick stalk, and an oblique annulus forming a complete ring which marks off the distal or peripheral face (to the left in Fig. 6) from the proximal or central 


\section{Bower.-Studies in the Phylogeny of the Filicales. VIII. 353}

face (right in Fig. 6). There is, however, a difference in outline, those of Loxsomopsis being more flattened, so that the annulus, though continuous as a complete ring, appears to form a margin to the almost discoid capsule. The degree of induration is limited in Loxsoma to some twenty cells or less at the side of the ring remote from the stalk, the rest making up about half of the ring not being indurated: in this they are reduced, and appear as a vestigial tract of the annulus. No distinct stomial group is seen in Loxsoma. ${ }^{1}$ In Loxsomopsis nearly three-quarters of the ring is indurated, and an obliquely lateral stomium is well defined. There are two ways in which the sporangium of Loxsoma may be interpreted in relation to that of Loxsomopsis on the one hand, and that of the Schizaeaceae on the other. The current interpretation is founded on the fact that the sporangium of Loxsoma appears to share with the Schizaeaceae and Gleicheniaceae the dehiscence in the median plane, and accordingly it is held to be in that respect relatively primitive. But the state now observed in Loxsomopsis suggests another possibility: viz. that Loxsoma itself may have been derived from a type with the features now seen in Loxsomopsis, and that its median dehiscence may have originated secondarily by rupture of the indurated distal portion of the annulus. That rupture actually occurs in the position which would be most convenient for the shedding of the spores in a sporangium in which half of the annulus is mechanically ineffective. The facts appear insufficient to form a basis for a settled opinion on this point: if the latter view be found correct, one of the most interesting points of Loxsoma for comparison with the Simplices which have median dehiscence would fall away.

Such considerations leave still unresolved the difficulty of transition from the types of sporangium with complete annulus and median dehiscence, as seen in the Gleicheniaceae and Schizaeaceae, to those which also have an oblique annulus, but lateral dehiscence. The biological advantage of the change is patent in any crowded sorus. The sporangial type of Gleichenia or Schizaea demands elbow-room laterally for effective shedding of the spores: room which could not be afforded where the parts are closely packed. The lateral dehiscence, whether by, means of an oblique or a vertical annulus, allows of the distal part of the ring being everted and the spores being shed distally. This is the natural method for gradate and mixed sori. It may be held that in these the annulus is the correlative of the annulus in the higher Simplices. What we require is evidence of how the transition came about. It seems that the comparison of the Simplices on the one hand with Loxsoma, and on the other with Loxsomopsis, does not even yet yield decisive evidence. But all that would be required to carry out the change would be the establishment of a region of imperfect induration of the cells of the ring of a more perfect sort than that seen in the Simplices, and a swing of its position to one side or the other.

\footnotetext{
1 Compare Ann. of Bot., vol. xxvii, Pl. XXXIV, Figs. $26 a$, c.
} 


\section{Bower.-Studies in the Phylogeny of the Filicales. VIII.}

On this last point the fact is significant that in Loxsomopsis notabilis the stomium may lie either right or left of the stalk (Figs. 4, 6). If such a difference as this be found between the individual sporangia of a single plant, it suggests that there is in them just that sort of plasticity of development of the annulus which would be required to effect the transition from median to lateral dehiscence. It is probable that such a transition has actually occurred more than once in the evolution of the Ferns, and the plasticity above suggested would support this view. A very clear instance is to be found among the Superficiales in Lophosoria quadripinnata, Gmel. ${ }^{1}$ Here the annulus is of essentially the same type as in Loxsomopsis, though with a less highly specialized stomium. It appears probable that while Loxsoma and Loxsomopsis illustrate the result of transition from the median to a lateral dehiscence in the Marginales, Lophosoria, and in the more exact degree Metaxya, show it among the Superficiales. The former instance might be traced to such a source as the living Schizaeaceae still illustrate: the latter clearly owe their origin to some such source as the Gleicheniaceae. These considerations appear to me to strengthen the view previously expressed ${ }^{2}$ that the Leptosporangiate Ferns progressed from very early times along two parallel lines, the one characterized by marginal, the other by a superficial position of their sori. As already shown elsewhere ${ }^{3}$ the distal position was probably general in the first instance for all Ferns. But as the leaf-blade expanded the marginal sorus slid to the lower surface, and it is probable that this has happened along many distinct phyletic lines, sometimes early, sometimes late in their evolution. In the Superficiales we may believe that it happened early: in the Marginales the marginal position was long retained; but ultimately the transition occurred, as indeed it is foreshadowed in the Schizaeaceae, and was carried out more fully in the Pteroideae.

The effect of the observations on Loxsomopsis, imperfect though they are, is to cast a doubt upon the validity of the median dehiscence of the sporangium of Loxsoma as a point of comparison with the Schizaeaceae. But nevertheless these two related genera will retain their interest as synthetic types of clearly primitive nature. They occupy in the marginal series of Ferns a position between the Schizaeaceae and the DicksonioidDavallioid-Pterid sequence: and this is comparable to that occupied by Lophosoria and Metaxya in the superficial series, between the Gleicheniaceae and the Cyatheoid-Dipterid-Dryopterid sequence.

1 Ann. of Bot., vol. xxvi, Pl. XXXV, Figs. 17-20.

3 The Ferns, Cambridge Press, vol. i, I923, pp. 2 16-25.

2 Ibid., vol. xxvii, p. 470. 


\section{$2 \mathrm{BHL}$ Biodiversity Heritage Library}

Bower, F. O. 1923. "Studies in the phylogeny of the Filicales. VIII. On Loxsoma and Loxsomopsis." Annals of botany 37, 349-354. https://doi.org/10.1093/oxfordjournals.aob.a089853.

View This Item Online: https://www.biodiversitylibrary.org/item/270686

DOI: https://doi.org/10.1093/oxfordjournals.aob.a089853

Permalink: https://www.biodiversitylibrary.org/partpdf/319090

\section{Holding Institution}

New York Botanical Garden, LuEsther T. Mertz Library

\section{Sponsored by}

BHL-SIL-FEDLINK

\section{Copyright \& Reuse}

Copyright Status: Public domain. The BHL considers that this work is no longer under copyright protection.

This document was created from content at the Biodiversity Heritage Library, the world's largest open access digital library for biodiversity literature and archives. Visit BHL at https://www.biodiversitylibrary.org. 